\title{
Friedrich Trendelenburg (1844-1924) and the trendelenburg position
}

\author{
M. Thiery
}

(C) Springer-Verlag 2009

The name Trendelenburg shall remain eponymously associated with diverse surgical interventions, instruments and clinical signs, but it is 'his' 'Beckenhochlagerung', the 'Raised Pelvic Position', ultimately known as the Trendelenburg Position, that is still being employed by all gynaecologists, surgeons and other health practitioners around the world and that has secured his name indelibly into the annals of medical history [1].

Friedrich Trendelenburg was born in Berlin on 24 May 1844 , the son of professor of philosophy Adolf Trendelenburg (1802-1872; Fig. 1) [2, 3]. He followed medical courses first in Edinburgh and Glasgow (candidatures for the degree) and subsequently in Berlin (doctoral studies), where he graduated in 1866 with a thesis entitled "De veterum Indorum chirurgia" (about ancient Indian medical practices). The advance and progress of medical history would be a topic that fascinated and inspired him for the rest of his long life.

After 2 years of military service as a doctor and surgeon in the hospitals of Gorlitz and Kiel, Friedrich Trendelenburg was appointed in 1868 as assistant to the Berlin Professor Bernhard von Langenbeck (1810-1887), a figurehead in experimental and general clinical surgery, founder of the 'Archiv für klinishe Chirurgie' and co-founder of the 'Deutsche Gesellschaft für Chirurgie'. In 1874, after a training programme that lasted 6 years, Friedrich Trendelenburg was

This article was originally published in Tijdschrift voor Geneeskunde. The English version is printed by permission of Prof. Dr. J. Lauweryns, Editor-in-Chief. Life Leuven is acknowledged for the translation.

M. Thiery $(\bowtie)$

Jan Palfyn Foundation and Museum for History of Medicine, Aan de Bocht 6,

9000 Gent, Belgium appointed Director of the Surgical Department at the 'Krankenhaus Friedrichshain (a hospital in Berlin), after which he forged for himself a strikingly rapid academic career as professor of surgery in Rostock (1875), Bonn (1882) and, finally, in Leipzig (1895), where he remained until his retirement in 1911.

Subsequently, he went to live in Nikolassee, near Berlin, where on 15 December 1924, he passed away as a result of mandibular sarcoma.

Friedrich Trendelenburg became a surgeon at a historically favourable moment, that is, after the introduction of inhalation narcosis and asepsis, two milestones that accelerated the pace of advances in surgical procedures. In addition, he had received a thorough training and was very versed in all branches of his discipline.

As we know from eponyms associated with his name, it is especially in the fields of orthopaedic, vascular, urological and gynaecological surgery that he has made his most significant contributions.

Already in 1871, his name had become internationally known because of the 'Tamponkanüle', so-called tampon cannula, a drainage tube with an inflatable rubber balloon for preventing patients from swallowing blood into the trachea following a tracheotomy, the instrument English surgeons continue to call the "Trendelenburg Cone" [4].

During the 1980s, Friedrich Trendelenburg became focused on the diagnosis and the treatment of varicose veins in the lower limbs. In 1890, he published two clinical tests to detect venous valve insufficiency and on a varicose operation, ligature of the vena saphena magna [5].

In 1895, a study was published about the congenital hip luxation and a new diagnostic sign for this disease: "Trendelenburgisches Zeichen" [6].

Trendelenburg's final major contribution to venous surgery was the pulmonary embolectomy [7]. This operation 


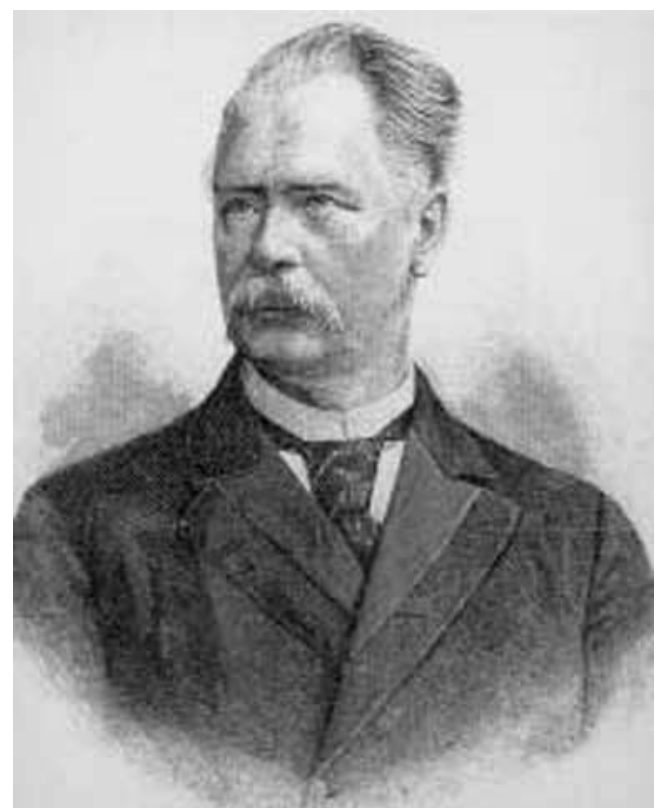

Fig. 1 Professor Friedrich Trendelenburg

proved not very successful, but with it, Trendeleneburg opened the door to its subsequent refinement.

The Trendelenburg Position - patient supine on a table tilted $45^{\circ}$ downwards with legs and feet over the edge of the table - was the 'egg of Columbus', a position necessary during abdominal and pelvic operations [8]. Trendelenburg began experimenting with this position in the 1880 s on patients suffering from a vesicovaginal fistula that could not be reached and treated via the ordinary vaginal route. Following trans-abdominal cystostomy, he put the patient in 'Beckenhochlagerung', the Raised Pelvic Position. The fistula cure was facilitated by this method: the surgeon can operate in a standing position, does not need to bend over and looks at the surgical area in the way a painter looks at his easel. He will subsequently also employ this position for gynaecological operations and advise his colleagues that this manner of a pan-hysterectomy operation is not more difficult to perform than the conventional supra-vaginal amputatio uteri. The Trendelenburg position reduces the blood supply to the genitals, and the application of a garrot on the v. and a. uterinae is superfluous.

Trendelenburg, who was a father figure to his collaborators, encouraged his assistants to publish. This then explains why it was his assistant Dr. Willy Meyer who first described the Raised Pelvic Position (1885) and introduced that term into the medical terminology, to which the Dutch gynaecologist Maurice Arthur Mendes de Leon (1856-1924) will in 1888 add the name of its 'inventor', the Trendelenburg Position.

In Meyer's article, we read that the 'Beckenhochlagerung' was originally achieved by letting the patient's legs rest on the shoulders of a strong assistant (Fig. 2). In later

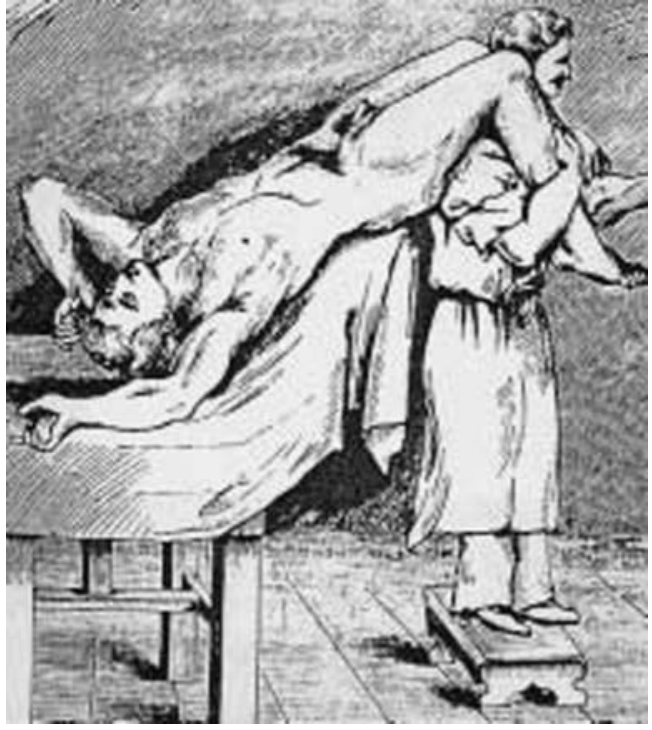

Fig. 2 The original application of the 'Beckenhochlagerung', (Meyer W. Ueber die Nachbehandlung des hogen Steinschnittes sowie über. Verwendbarkeit desselben zur Operation von Blasenscheidenfisteln. Arch. Klin. Chir. 1884; 31; 494)

years, the surgeon will relieve his assistant from that chore by having a special operating table constructed (Fig. 3). Only in 1890 did Trendelenburg make mention of his 'Position' in an article about the fistula operation and the application of other gynaecological procedures [8].

Trendelenburg was not the 'inventor' of the 'Raised Pelvic Position'. The principle was already mentioned by Celsus (40-20 BC), and Paulus Aegineta (625-690) and Abulcasis (936-1013) already used this position in treating abdominal injuries. The procedure was also used by those practising 'abdominal incisions'.

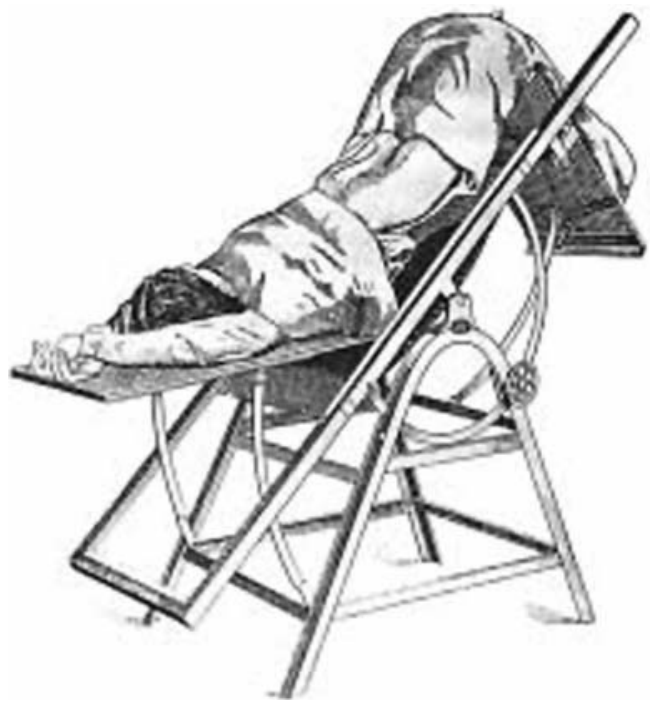

Fig. 3 The operating table Trendelenburg depicted in an 1895 catalogue of medical instruments and equipment 
Gutberlet introduced this position in gynaecology. In the removal of the uterus, he made use of a hard pillow placed underneath the thighs of the woman [3]. Nonetheless, notwithstanding these historical applications, we are of the opinion that the eponym is not out of place; Trendelenburg popularised the position and had a special operating table constructed specifically to serve and facilitate the operation.

\section{References}

1. De Haan HR, Dekker WA (1956) Groot Woordenboek der Geneeskunde. L. Stafleu, Leiden
2. Fischer I (1962) Biographisches Lexikon der hervorragenden Aerzte der letzten fünfzig Jahre. Urban und Schwarzenberg, München

3. Speert H (1957) Friedrich Trendelenburg and the Trendelenburg Position. Surg Gynec Obstet 105:114

4. Trendelenburg F (1871) Beiträge zu den Operationen an den Luftwegen. Arch Klin Chir 12:112

5. Trendelenburg F (1870) Ueber die Unterbinding der Vena saphena magna bei Unterschenkenvaricen. Beitr Klin Chir 7:195

6. Trendelenburg F (1895) Ueber den Gang bei angeborener Hüftgelenksluxation. Dtsch Med Wochenschr 21:21

7. Trendelenburg F (1908) Ueber die operative Behandlung der Embolie der Lungenarterie. Arch Klin Chir 86:687

8. Trendelenburg F (1890) Ueber Blasenscheidenfisteloperationen und über Beckenhochlagerung bei Operationen in der Bauchhöhle. Samml Klin Vortr 355(Chir., no 109):3372 